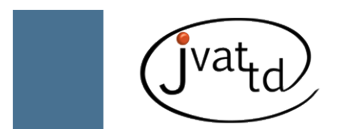

\title{
Correlation between serum levels of interleukins 10 and 12 and thrombocytopenia in hepatitis C cirrhotic (class A) patients
}

\author{
Abdallah N (1), Abdel Aziz HK (2), Hamed NA (3), Gamal M (4)
}

(1) Department of Tropical Medicine, Faculty of Medicine, Alexandria University, Alexandria, Egypt; (2) Department of Medical Biochemistry, Faculty of Medicine, Alexandria University, Alexandria, Egypt; (3) Department of Internal Medicine, Hematology Unit, Faculty of Medicine, Alexandria University, Alexandria, Egypt; (4) Department of Microbiology and Immunology, Faculty of Medicine, Alexandria University, Alexandria, Egypt.

\begin{abstract}
Hepatitis C virus (HCV) patients commonly have low platelet counts; however, the exact role of $\mathrm{HCV}$ infection in thrombocytopenia is unknown. This work aimed to study the serum levels of interleukins (IL) 10 and 12 in patients with mild and moderate thrombocytopenia associated with chronic hepatitis C infection. Our study included 15 patients with chronic HCV infection and newly diagnosed isolated autoimmune thrombocytopenia (Group I) and 15 patients with chronic HCV infection and normal platelet count as controls (Group II). All patients were examined for personal history and clinical aspects, complete blood count, bone marrow aspiration, liver function tests, HCV antibody assay by ELISA and polymerase chain reaction (PCR), abdominal ultrasound, Helicobacter pylori stool antigen test, evaluation of serum levels of IL-10, IL-12 and platelet specific antibodies. Our results revealed that eight patients from Group I had mild thrombocytopenia and seven patients had moderate thrombocytopenia. Serum IL-10 level was significantly elevated $(t=9.301, p<0.001)$ while serum IL-12 showed a significant decrease $(t=6.502, p$ $<0.001$ ) in Group I compared to the control group. No correlation was detected between platelet counts and the serum levels of either IL-10 [r=0.454, $p=0.089$ (Group I), $r=0.038, p=0.89$ (Group II)] or IL-12 [r= 0.497, $p=0.06$ (Group I), $r=0.499, p=0.058$ (Group II)]. However, in Group I, a significant correlation was present only between moderate thrombocytopenia and serum levels of either IL-10 $(r=0.794, p=0.033)$ or IL-12 $(r=0.967, p=0.001)$, while no correlation was detected between these interleukin parameters and mild thrombocytopenia ( $r=0.311$ and $p=0.453$ for IL-10 and $r=-0.08$ and $p=0.851$ for IL-12). Based on our data, we may conclude that interleukins 10 and 12 are involved in low platelet levels.
\end{abstract}

Key words: interleukin-10, interleukin-12, thrombocytopenia, hepatitis C activity.

\section{INTRODUCTION}

Thrombocytopenia is a common complication in patients with chronic liver disease. A platelet count less than $150.000 / \mu \mathrm{L}$ has been observed in up to $76 \%$ of patients. Moderate thrombocytopenia (platelet count ranging from 50,000 to $75,000 /$ $\mu \mathrm{L}$ ) occurs in approximately $13 \%$ of patients with cirrhosis (1). Infection with hepatitis $C$ virus (HCV) is a major cause of chronic liver diseases. $\mathrm{HCV}$ antibody-positive individuals are 2.6 times more likely to have a low platelet count than those who are HCV-antibody negative (2).
In untreated hepatitis $\mathrm{C}$ patients, both prevalence and severity of thrombocytopenia increase in parallel with the extent of the disease, usually becoming clinically relevant when patients develop extensive fibrosis and/or cirrhosis (3).

The pathophysiology of thrombocytopenia in patients with chronic liver disease resulting from HCV infection is complex and involves several complementary mechanisms that may act in concert. Pathogenetic mechanisms comprise hypersplenism secondary to portal hypertension, bone marrow suppression resulting from either HCV itself or interferon treatment, 
aberrations of the immune system provoking the formation of antiplatelet antibodies and/ or immune complexes that bind to platelets and facilitate their premature clearance, crossreactivity of antiplatelet glycoprotein antibodies and viral antigens (antigenic mimicry) $(3,4)$. Development of immunologically-mediated extrahepatic manifestations including mixed cryoglobulinemia with or without associated joint, renal or cutaneous involvement and thrombopoietin deficiency secondary to liver dysfunction constitute another postulated mechanisms (3).

Thrombocytopenia can potentially postpone or interfere with diagnostic and therapeutic procedures including liver biopsy, antiviral therapy, and medically indicated or elective surgery (1). In the present study, we evaluated the levels of interleukins 10 and 12 in patients presenting different degrees of autoimmune thrombocytopenia associated with chronic hepatitis $\mathrm{C}$ infection.

\section{PATIENTS AND METHODS}

The present study included 15 patients with chronic hepatitis $\mathrm{C}$ virus infection associated with newly diagnosed isolated autoimmune thrombocytopenia (Group I) and 15 patients with chronic hepatitis $\mathrm{C}$ and normal platelet count as the control group (Group II). The two groups were matched for age and sex. All patients had liver cirrhosis Child class A. Patients with evidence of hypersplenism, previous recent therapy with interferon or ribavirin, positive serology for HBV, HIV or positive $H$. pylori antigen in the stool were excluded from the study.

All patients were subjected to:

- Thorough history taking and clinical examination with special emphasis on immunologically-mediated extrahepatic manifestations including joint, renal or cutaneous involvement.

- Complete blood count and bone marrow aspiration (to exclude dysplastic changes) (5).

- Liver function tests including serum total protein, albumin, bilirubin, ALT and AST using commercially available kits (Boehringer Mannheim, Germany) (6).

- Detection of antibodies against hepatitis C virus by ELISA technique; Murex anti-HCV (version III) (7).
- Detection of HCV RNA by PCR, after it was extracted from $200 \mu \mathrm{L}$ of serum by the Trizol method (RNA Isolation ${ }^{\otimes}$ Life Technologies, USA) (8). The NS 5' region of $\mathrm{HCV}$ was amplified by reverse transcription and nested utilizing the biotinylated primers from the INNO-LIPA HCV amplification kit (UK) and ready-to-go-PCR beads (Amersham Pharmacia Biotech, UK).

- Amplified products were visualized with ethidium bromide by gel electrophoresis on a 302-nm UV illuminator.

- Abdominal ultrasound.

- Helicobacter pylori antigen analysis in stool (9).

- Platelet specific antibodies by modified antigen-capture ELISA.

- Serum level estimation of IL-10 and IL-12 by Diaclone ELISA biotinylated assay (France).

\section{Statistical analysis}

The SPSS package, version 9.0 for Windows ${ }^{\oplus}$ (Microsoft, USA), was used for statistical analysis of data. Student's t-test was employed to compare means of age, hematological and chemical parameters between patients and the control group. The $\chi^{2}$-test was utilized for comparison of sex distribution into Group I or Group II. Associations between the different studied variables were evaluated with Pearson's correlation $(r) ; p \leq 0.05$ was considered significant. Data are shown as mean \pm standard deviation (SD).

\section{RESULTS}

The clinical and laboratory data of the studied groups are shown, respectively, in Tables 1 and 2. Clinically evident bleeding was present in nine out of $15(60 \%)$ patients in the form of recurrent epistaxis and gingival bleeding.

Mild thrombocytopenia (platelet count > $75,000 / \mu \mathrm{L}$ and $<150,000 / \mu \mathrm{L}$ ) was present in eight out of 15 (53\%) patients whereas moderate thrombocytopenia (platelet count between $50,000 / \mu \mathrm{L}$ and $75,000 / \mu \mathrm{L}$ ) was found in seven out of 15 (47\%) individuals (1).

Table 3 presents the correlation between platelet counts and serum levels of interleukins 10 and 12 in HCV positive group associated with moderate thrombocytopenia. No correlation was detected between platelet count and the serum levels of either IL-10 $(r=-0.038, p=0.89$ for 
Table 1. Clinical data of the studied groups

\begin{tabular}{c|c|c|c}
\hline Parameter & Group I $(\mathbf{n}=15)$ & Group II $(\mathbf{n}=15)$ & $\begin{array}{c}\text { Significance test } \\
(\mathbf{p} \text {-value })\end{array}$ \\
\hline Age (years) & $58 \pm 4.34$ & $55.47 \pm 5.95$ & $>0.05$ \\
\hline Sex & 8 & 6 & $>0.05$ \\
\hline Female & 7 & 9 & - \\
\hline Evident bleeding & 9 & - & - \\
\hline $\begin{array}{c}\text { Degree of thrombocytopenia } \\
\text { Mild } \\
\text { Moderate }\end{array}$ & 8 & - & \\
\hline
\end{tabular}

Group I: patients with chronic hepatitis-C-infection-associated thrombocytopenia; Group II: patients with chronic hepatitis $C$ infection and normal platelet count (control group); $p$ is significant if $\leq 0.05$.

Table 2. Laboratory data of the studied groups

\begin{tabular}{c|c|c|c}
\hline Parameter & Group I $(\mathbf{n}=15)$ & Group II $(\mathbf{n}=15)$ & $\begin{array}{c}\text { Significance test } \\
\text { ( } \mathbf{p} \text {-value) }\end{array}$ \\
\hline AST $(\mathrm{U} / \mathrm{L})$ & $56.73 \pm 12.18$ & $33 \pm 3.36$ & $\begin{array}{c}7.275 \\
<0.001\end{array}$ \\
\hline ALT (U/L) & $56.6 \pm 13.12$ & $33.13 \pm 3.42$ & $\begin{array}{c}5.847 \\
0.016\end{array}$ \\
\hline Platelets $(\times 109 / \mathrm{L})$ & $78.8 \pm 19.98$ & $213.2 \pm 51.07$ & $\begin{array}{c}-9.492 \\
<0.001\end{array}$ \\
\hline IL-12 $(\mathrm{pg} / \mathrm{mL})$ & $5.93 \pm 4.08$ & $20 \pm 7.32$ & $\begin{array}{c}-6.502 \\
<0.001\end{array}$ \\
\hline IL-10 $(\mathrm{pg} / \mathrm{mL})$ & $16.63 \pm 3.35$ & $7.47 \pm 1.83$ & $\begin{array}{c}9.301 \\
<0.001\end{array}$ \\
\hline
\end{tabular}

Group I: patients with chronic-hepatitis-C-infection-associated thrombocytopenia; Group II: patients with chronic hepatitis C infection and normal platelet count (control group); $\mathrm{p}$ is significant if $\leq 0.05$.

Table 3. Correlations between platelet counts and interleukins 10 and 12 in HCV-positive cirrhotic patients associated with moderate thrombocytopenia

\begin{tabular}{c|c|c}
\hline Parameter & Platelets $\left(\times 10^{9} / \mathrm{L}\right)$ & $\mathrm{IL}-10(\mathrm{pg} / \mathrm{mL})$ \\
\hline Platelets $\left(\times 10^{9} / \mathrm{L}\right)$ & & - \\
$\mathrm{r}$ & - & \\
\hline $\mathrm{f})$ & & 0.760 \\
$\mathrm{IL}-12(\mathrm{pg} / \mathrm{mL})$ & 0.967 & 0.047 \\
\hline $\mathrm{p})$ & 0.001 & \\
\hline $\mathrm{IL}-10(\mathrm{pg} / \mathrm{mL})$ & & - \\
(p) & 0.794 & \\
\hline
\end{tabular}

$p$ is significant if $\leq 0.05$. 
controls; $\mathrm{r}=0.454, \mathrm{p}=0.089$ for $\mathrm{HCV}$ positive group associated with thrombocytopenia) or IL$12(\mathrm{r} \quad 0.499, \mathrm{p}=0.058$ for controls, $\mathrm{r}=0.497$; $\mathrm{p}=0.06$ for $\mathrm{HCV}$ positive group associated with thrombocytopenia). However, moderate thrombocytopenia was significantly correlated with serum levels of both IL-10 ( $\mathrm{r}=0.794$, $\mathrm{p}=0.033)$ and IL-12 ( $\mathrm{r}=0.967, \mathrm{p}=0.001)$; although such correlation was not detected in mild thrombocytopenia $(\mathrm{r}=0.311, \mathrm{p}=0.851$ for IL-10 and $r=-0.08, p=0.453$ for IL-12). The respective mean values of interleukins 10 and 12 in HCV positive cirrhotic patients associated with moderate thrombocytopenia were: $15.86 \pm$ $3.89 \mathrm{pg} / \mathrm{mL}$ and $4.57 \pm 4.45 \mathrm{pg} / \mathrm{mL}$.

\section{DISCUSSION}

HCV infection may be associated with significant thrombocytopenia and appears to be a distinct clinical entity (10). Moderate thrombocytopenia was present in seven out of 15 (47\%) patients while mild thrombocytopenia was detectable in eight out of 15 (53\%). In a previous study of HCV-thrombocytopenic patients, 4\% had severe thrombocytopenia $\left(\leq 10 \times 10^{9} / \mathrm{L}\right)$ while $74 \%$ had a maximum platelet count of 50 x $10^{9} / \mathrm{L}(10)$.

The mean age of our patients was 58 years in Group land 55 years in Group II with no statistically significant difference between the two groups as to age or sex. The prevalence of thrombocytopenia in older persons with HCV infection was 6.6 times greater than that among the elderly without HCV infection and equally distributed between genders. Anti-HCV-positive older individuals were three times more likely than persons in other age groups to have thrombocytopenia. This might be related to poorly compensated platelet production, especially in individuals with severe liver disease (11).

In our study bleeding was clinically evident in nine out of 15 (60\%) studied thrombocytopenic patients in the form of recurrent epistaxis and gum bleeding. The majority of older individuals with anti-HCV and thrombocytopenia are asymptomatic, but major bleeding was more frequent (10).

Similarly, in the current work, all patients had liver cirrhosis Child class A. HCV-infectionassociated thrombocytopenia was correlated with hepatocellular damage and hepatic fibrosis (11). The prevalence of thrombocytopenia increased markedly with liver disease severity among patients with HCV infection; the prevalence was about nine times higher among subjects with chronic hepatitis, cirrhosis, or hepatoma than among those with a normal or fatty liver (11).

The exact role of HCV infection in the occurrence of thrombocytopenia is unknown. An impaired thrombopoietin (TPO) production did not explain the development of thrombocytopenia in $\mathrm{HCV}$ infection. It was suggested that TPO production is maintained at certain levels until profound impairment of hepatic function has developed, when other organs may compensate the decrease in TPO production by the liver (2). Therefore, other mechanisms must be involved.

Dysregulation of T-helper (Th1/Th2) cytokine production may play an important role in immunopathogenesis of chronic hepatitis C (CHC) (12). In $\mathrm{CHC}$ patients, interferon- $\gamma$ (IFN- $\gamma$ ) and IL-12 levels drop as a result of the enhanced IL-10 production, which serves as a possible down-regulator of IFN- $\gamma$ (13). Further research on the role of these cytokines in HCV infection associated with thrombocytopenia may clarify additional functions of these cytokines.

IL-10 is an important immunoregulatory cytokine and its main biological functions seem to be the limitation and termination of inflammatory responses and the regulation of differentiation and proliferation of T cells, B cells, natural killer cells, antigen-presenting cells, mast cells and granulocytes. Moreover, IL-10 promotes the development of a type 2 cytokine pattern by inhibiting IFN- $\gamma$ production (14).

The present study revealed statistically significant elevation in serum IL-10 levels in Group I (HCV associated with thrombocytopenia) when compared with Group II. HCV-specific IL-10 response was detected within one to two months of acute clinical hepatitis C (15). IL10 has been reported to be one of the potential factors in establishing immune suppression and viral persistence (16). The present study revealed statistically significant decrease in IL-12 levels in Group I in relation to controls.

IL-12 is a proinflammatory cytokine produced by dendritic cells and phagocytes in response to pathogens during infection (17). It plays a central role in coordinating innate and adaptive immunity. Expression of IL-12 during infection regulates innate responses and determines the type and duration of adaptive immune 
response. Additionally, this cytokine induces IFN- $\gamma$ production by natural killer cells, $\mathrm{T}$ cells, dendritic cells and macrophages, and promotes the differentiation of naive CD4+ T cells into Th1 cells that produce IFN- $\gamma$ and aid in cell-mediated immunity (18).

In the present study, no correlation was detected between platelet counts and serum levels of either IL-10 or IL-12 in Group I or II. However, in Group I, a significant correlation was detected between moderate thrombocytopenia and serum levels of both IL-10 and IL-12, although this connection was not present in mild thrombocytopenia. Elevated IL-10 serum levels in chronic HCV patients were not associated with different laboratory parameters, histological activity index or HCV-RNA viral load for any of the patient population (19).

\section{CONCLUSIONS}

The present results reveal the presence of a function of interleukins 10 and 12 at lower platelet levels together with other factors. Further studies are still required to confirm and explain this relationship. If these findings are confirmed, these cytokines may be a marker of moderateto-severe thrombocytopenia in chronic $\mathrm{HCV}$ patients.

\section{COPYRIGHT}

(c) CEVAP 2010

\section{SUBMISSION STATUS}

Received: November 4, 2009.

Accepted: March 3, 2010.

Abstract published online: March 22, 2010.

Full paper published online: August 31, 2010.

\section{CONFLICTS OF INTEREST}

There is no conflict.

\section{CORRESPONDENCE TO}

HANAN KAMAL ABDEL AZIZ, 124 Taawniat Smouha, Alexandria, 21431, Egypt. Phone: +20 127681628. Email: hanankam60@yahoo.com.

\section{REFERENCES}

1. Afdhal N, McHutchison J, Brown R, Jacobson I, Manns M, Poordad F, et al. Thrombocytopenia associated with chronic liver disease. J Hepatol. 2008;48(6):1000-7.

2. Afifi OA, Sewify EM, El-Attar MM, Taie AO,
Mostafa AK. Hepatitis C virus-associated thrombocytopenia is not related to serum thrombopoietin levels. Saudi J Gastroenterol. 2007;13(2):76-80.

3. Weksler BB. Review article: the pathophysiology of thrombocytopenia in hepatitis $C$ virus infection and chronic liver disease. Aliment Pharmacol Ther. 2007;26(Suppl 1):13-9.

4. Liebman H. Other immune thrombocytopenias. Semin Hematol. 2007;44(4 Suppl 5):S24-34.

5. Dacie JV, Lewis SM. Practical haematology. $8^{\text {th }}$ ed. Edinburgh: Churchill Livingstone; 1995. p. 4985, 143- 74 .

6. Gowenlock AH. Varley's practical clinical biochemistry. 6th ed. London: Heinemann Book; 1987. p. 715-89.

7. McHutchison JG, Person JL, Govindarajan S, Valinluck B, Gore T, Lee SR, et al. Improved detection of hepatitis $\mathrm{C}$ virus antibodies in highrisk populations. Hepatology. 1992;15(1):19-25.

8. Kato N, Yokosuka O, Omato M, Hosoda K, Ohto M. Detection of hepatitis $\mathrm{C}$ virus ribonucleic acid in the serum by amplification with polymerase chain reaction. J Clin Invest. 1990;86(5):1764-7.

9. Blebea J, McPherson RA. False-positive guaiac testing with iodine. Arch Pathol Lab Med. 1985;109(5):437-40.

10. Rajan SK, Espina BM, Liebman HA. Hepatitis C virus-related thrombocytopenia: clinical and laboratory characteristics compared with chronic immune thrombocytopenic purpura. $\mathrm{Br}$ J Haematol. 2005;129(6):818-24.

11. Wang CS, Yao WJ, Wang ST, Chang TT, Chou P. Strong association of hepatitis C virus (HCV) infection and thrombocytopenia: implications from a survey of a community with hyperendemic HCV infection. Clin Infect Dis. 2004;39(6):790-6.

12. Fan XG, Liu WE, Li CZ, Wang ZC, Luo LX, Tan $\mathrm{DM}$, et al. Circulating Th1 and Th2 cytokines in patients with hepatitis C virus infection. Mediators Inflamm. 1998;7(4):295-7.

13. Piazzolla G, Tortorella C, Schiraldi O, Antonaci S. Relationship between interferon-gamma, interleukin-10 and interleukin-12 production in chronic hepatitis $\mathrm{C}$ and in vitro effects of interferon-alpha. J Clin Immunol. 2000;20(1):5461.

14. Asadullah K, Sterry W, Volk HD. Interleukin-10 therapy: review of a new approach. Pharmacol Rev. 2003;55(2):241-69.

15. Kaplan DE, Ikeda F, Li Y, Nakomoto N, Ganesan $S$, Valiga ME, et al. Peripheral virus-specific T-cell interleukin-10 responses develop early in acute hepatitis $\mathrm{C}$ infection and become dominant in chronic hepatitis. J Hepatol. 2008;48(6):903-13.

16. Ha SJ, West EE, Araki K, Smith KA, Ahmed 
R. Manipulating both the inhibitory and stimulatory immune system towards the success of therapeutic vaccination against chronic viral infections. Immunol Rev. 2008;223(1):317-33.

17. Trinchieri G. Interleukin-12 and the regulation of innate resistance and adaptive immunity. Nat Rev Immunol. 2003;3(2):133-46.

18. Watford WT, Moriguchi M, Morinobu A, O'Shea JJ. The biology of IL-12: coordinating innate and adaptive immune responses. Cytokine Growth Factor Rev. 2003;14(5):361-8.

19. Emam EA, Emam M, Shehata AE, Emara M. Impact of Schistosoma mansoni co-infection on serum profile of interferon-gamma, interleukin-4 and interleukin-10 in patients with chronic hepatitis C virus infection. Egypt J Immunol. 2006;13(2):33-40. 